\title{
Genetic variation of Pinus pinaster Ait. seedlings in susceptibility to the pine weevil Hylobius abietis L.
}

\author{
Rafael ZAS $^{\mathrm{a} *}$, Luis SAMPEDRO ${ }^{\mathrm{b}}$, Eva PRADA ${ }^{\mathrm{a}}$, Josefa FERNÁNDEZ-LóPEZ ${ }^{\mathrm{a}}$ \\ a Departamento de Producción Forestal, Centro de Investigacións Forestais e Ambientais de Lourizán, Apdo. 127, Pontevedra, 36080 Spain \\ b Departamento de Ecoloxía, Centro de Investigacións Forestais e Ambientais de Lourizán, Apdo. 127, Pontevedra, 36080 Spain
}

(Received 30 September 2004; accepted 1 April 2005)

\begin{abstract}
Damage by the pine weevil Hylobius abietis L. (Coleoptera: Curculionidae) on Pinus pinaster Ait. was evaluated in a fertilization $\times$ progeny test in Galicia (NW Spain) to determine the genetic variation among families and the possibility to include the resistance to this insect as a selection criteria in the Galician maritime pine breeding program. Several damage and symptoms traits were evaluated. All these traits showed highly significant family effects and were strongly correlated among each other. Individual and family heritability estimates of the wound evaluations in the seedling stems were around 0.2 and 0.8 , respectively. Strong genetic correlations among wounds and the average seedling color indicated that this last simple and subjective trait can be used for screening for pine weevil susceptibility. A positive genetic correlation was also observed between diameter growth and pine weevil damage. Faster growing families were more attacked hindering the possibility to include the susceptibility to the insect in the breeding program.
\end{abstract}

Pinus pinaster / Hylobius abietis / genetic parameter / genetic resistance / pest management

Résumé - Variation génétique de la susceptibilité des jeunes plants de pin maritime à Hylobius abietis L. Les dommages provoqués par Hylobius abietis L. (Coleoptera : Curculionidae) au pin maritime (Pinus pinaster Ait.) ont été évalués sur un test génétique de descendances maternelles soumis à différents traitements de fertilisation en Galice (NO Espagne). Le but était d'étudier la variation entre familles du niveau d'attaque de l'insecte et la possibilité d'inclure ce caractère dans le programme d'amélioration du pin maritime en Galice. Différents dégâts et symptômes ont été mesurés ainsi que la hauteur et le diamètre. Tous les traits évalués ont montré un effet famille très significatif et ils ont souvent corrélés entre eux. Les blessures évaluées au niveau de la tige du jeune plant montrent une héritabilité individuelle et familiale d'environ 0,2 et 0,8 respectivement. Le nombre de blessures sur la tige et la couleur des jeunes plants sont corrélés génétiquement. Il semble donc possible d'utiliser cette mesure de coloration, simple et subjective, pour évaluer la sensibilité du pin à l'hylobe. Nous avons aussi observé une corrélation génétique positive entre la croissance en diamètre et les dommages dus à $H$. abietis. Les familles les plus vigoureuses ont été les plus attaquées, ce qui limite les possibilités d'inclure la sensibilité à l'insecte dans le programme d'amélioration du pin maritime.

Pinus pinaster / Hylobius abietis / paramètres génétiques / résistance génétique / gestion parasitaire

\section{INTRODUCTION}

Plants usually show high genetic variation in plant susceptibility to insect pests [34]. This variation affects insect performance, insects commonly preferring plants with high quality tissues and low plant defensive responses [5, 45]. Farmers and foresters have also exploited this genetic variation developing resistant genotypes through selective breeding. Several morphological and anatomical characters, the chemical tissue composition, the properties of the resin flow, the density of resin canals, the capacity to produce induced defensive responses, differences in phenology, the presence of feeding repellents, deterrents or toxic compounds, etc. can be implicated in this genetic resistance $[1,17]$.

In conifers, strong genetic variation have been reported in resistance of several species to insects feeding on leaves, bark and phloem $[15,16,18,19,36]$. Besides this observed intraspe- cific genetic variation, the environmental conditions are also determining the phenotypic expression of plant resistance and modifying the herbivore-host system. For instance, changes in resource availability for the plant (namely soil fertility, water and light regime) could modify the allocation of carbon resources in both induced and constitutive defenses, leading to altered herbivore resistance and plant growth [23]. Moreover, plant genotype and environmental conditions can interact leading to different responses of a genotype in a range of variation of environmental factors (e.g. [10,32]). Several ecological theories have been proposed to explain the modification in resource allocation as a response to environmental stress and herbivory (e.g. [12, 24, 25, 42]).

The pine weevil Hylobius abietis L. is a major problem for successful conifer regeneration in recently harvested conifer stands of Europe. Adults feed on the bark of young seedlings causing important growth losses, stem deformation and high

\footnotetext{
* Corresponding author: rzas.cifal@siam-cma.org
} 
Table I. Codes and chemical composition of the fertilization treatments. The + and - signs indicate presence and absence of a given compound in the fertilizer treatment, respectively.

\begin{tabular}{|c|c|c|c|c|c|c|c|c|c|c|c|}
\hline \multirow{2}{*}{ Nutrient } & \multirow{2}{*}{ Fertilizer } & \multirow{2}{*}{ Dose } & \multicolumn{9}{|c|}{ Treatment code } \\
\hline & & & control & $\mathrm{F} 1$ & $\mathrm{~F} 2$ & F3 & F4 & F5 & F6 & F7 & F8 \\
\hline $\mathrm{N}$ & Ammonium nitrate & $5 \mathrm{~g} \mathrm{~N}$ plant $^{-1}$ & - & + & - & + & + & + & - & - & - \\
\hline $\mathrm{P}-\mathrm{Ca}$ & Calcium phosphate & $10 \mathrm{~g} \mathrm{P}$ plant $^{-1}$ & - & + & + & - & + & + & - & + & + \\
\hline $\mathrm{K}$ & Potassium sulfate & $15 \mathrm{~g} \mathrm{~K}$ plant $^{-1}$ & - & + & + & + & - & + & + & - & + \\
\hline $\mathrm{Mg}$ & Magnesium sulfate & $5 \mathrm{~g} \mathrm{Mg}$ plant $^{-1}$ & - & + & + & + & + & - & + & + & - \\
\hline
\end{tabular}

mortality $[22,44]$. Seedling mortality after plantation can reach $60-80 \%$ if no preventive silvicultural measures are applied [33]. Preventive practices include delayed planting, soil scarification, shelterwood, feeding barriers, vegetation control or insecticide applications [33, 35, 40]. Mortality can be drastically reduced combining some of these silvicultural methods [35]. Despite the important effort to find out effective prophylactic methods against weevil damage, none has resulted completely successful. In the context of the reduction of pesticide use in European forests, the possibility of breeding for genetic resistance appears as a promising tool for weevil management [2]. Besides, an integrative breeding program should consider that genetic improvement of growth traits is not leading to undesired side effects such as greater pest susceptibility.

H. abietis damages affect many conifers in Europe including maritime pine (Pinus pinaster Ait.) which is one of the most important forest tree species of Galicia. Actually, maritime pine is the most commonly planted species in this region with an annual plantation rate of about 7000 ha [4]. A breeding program for maritime pine in Galicia was started in the 80's looking forward to improve growth, stem form and branching characteristics [49]. Given the importance of nutritional factors in the productivity of many forest species in Galicia [29, 38, 47,48 ] several progeny $\times$ fertilization trials were established in order to test the impact of soil fertility and fertilization in the performance of the improved material. The massive attack of $H$. abietis in one of these trials gave us the opportunity to test how fertilization and genotype affect the pine weevil damage. The effect of fertilization on pine weevil damage has been presented in a companion paper [51].

The objectives of this study were (i) to determine the level of genetic variation in the susceptibility to pine weevil damage in a subset of the actual $P$. pinaster breeding population in Galicia, (ii) to examine the viability of different damage traits for operational breeding and (iii) to determine the genetic relation between resistance to pine weevil and growth capability.

\section{MATERIALS AND METHODS}

\subsection{Site description}

The study was conducted on a progeny $\times$ fertilization trial located nearby the sea in Galicia (Rianxo, NW Spain, $42.60^{\circ} \mathrm{N}, 8.77^{\circ} \mathrm{W}$, altitude $90 \mathrm{~m}$ ). The trial was established on March 2003, one year after the previous $35 \mathrm{yr}$-old $P$. pinaster stand was clear-cut harvested. The climate is Atlantic with high annual $(\sim 2000 \mathrm{~mm})$ and summer $(\sim 170 \mathrm{~mm}$ in July and August) precipitation, and low annual temper- ature oscillation $\left(11^{\circ} \mathrm{C}\right.$ between the coldest and the warmest month). The soil is a typical acidic and sandy forest soil on granites. It has $\mathrm{pH}$ in $\mathrm{H}_{2} \mathrm{O}$ around 4.5, high organic matter content (170 $\mathrm{g}$ ash free dried weight $\left.\mathrm{kg}^{-1}\right)$, high total Kjeldahl nitrogen concentration $\left(8.3 \mathrm{~g} \mathrm{~N} \mathrm{~kg}^{-1}\right)$ and low levels of nutrients, especially of available phosphorus $\left(\mathrm{P}\right.$ Oslen $\left.=5.2 \mathrm{mg} \cdot \mathrm{kg}^{-1}\right)$.

The damage by the pine weevil started around 4 months after plantation and it was uniformly distributed in all the experimental surface area [51], which was surrounded all around by mature maritime pine stands.

\subsection{Plant material}

The study material consisted of open-pollinated families of 28 plus trees randomly selected in a first generation seed orchard (Sergude, $42.82^{\circ} \mathrm{N}, 8.45^{\circ} \mathrm{W}$ ) which provides high genetic quality seed for reforestation in the Atlantic coast of Galicia. All these plus trees were selected within the Atlantic-Coast provenance for superior growth, stem form and branch characteristics. Two unimproved seed sources were also included as controls: the TC and TI, which are commercial seeds commonly used in the coastal and interior area of Galicia, respectively.

\subsection{Fertilization treatments}

Eight fertilization treatments (built upon combinations of four commercial fertilizers, Tab. I) plus an unfertilized control were applied at the establishment. The fertilizers were spread by hand on a $30 \mathrm{~cm}$ diameter circle around the seedlings.

\subsection{Experimental layout}

The experimental layout was a randomized split-plot design replicated in 10 blocks, with the nine fertilization treatments acting as the whole factor, and the 30 seed sources as the split factor. Spacing was $2 \times 3 \mathrm{~m}$.

\subsection{Assessment}

Total height $(\mathrm{H})$ and ground line diameter (D) were measured in all living plants one year after plantation. Height of those plants with dead leader was not measured. Pine weevil damage was measured by evaluating the wounds in the stem caused by the insect. To avoid subjectivity, the stem height was divided in ten parts using an elastic ruler, and wounds were evaluated in each resulting tenth using a 4-levels scale $(0=$ undamaged, $1=$ some wounds, $2=$ many wounds, and $3=$ death due to girdling). The sum of these ten values by plant, expressed as percentage, was the damage trait 'wounds' (WND). Additionally, the leader loss (LL) due to stem girdling by the pine weevil was also recorded as a percentage of the total height using a discrete 6-level scale from $0 \%$ to $100 \%$ by $20 \%$. 
The WND trait was a reliable measure of the pine weevil damage but it was very hard to assess. In order to explore other practical traits for operational breeding, several symptoms traits were also considered. Seedlings were visually scored for foliage color (COL), foliage density (DEN) and amount of resin in the stem (RES). These three traits were subjectively assessed on a scale from 1 (yellow foliage, low foliage density and many resin on the stem) to 4 (green foliage, no needle loss and no resin on the stem). All assessments were made by the same person.

\subsection{Statistical analyses}

All traits were analyzed by the following linear model:

$$
H_{i j k}=\mu+F_{i}+G_{j}+B_{k}+F G_{i j}+G B_{j k}+F B_{i k}+\varepsilon_{i j k}
$$

where $H_{i j k}$ is the value of the trait, $\mu$ is the overall mean, $F_{i}, G_{j}$ and $B_{k}$ are the main effects of fertilization $i$ ( $i=1$ to 9 ), family $j(j=1$ to 28 ) and block $k(k=1$ to 10$), F G_{i j}, G B_{j k}$ and $F B_{i k}$ are the corresponding interactions and $\varepsilon_{i j k}$ is the experimental error. To analyze the whole plot factor (i.e. fertilization) with the appropriate error term, the $\mathrm{F} \times \mathrm{B}$ interaction was considered a random effect. The genotype and all the interactions involving this factor were also considered random. Fertilization and block were considered fixed effects. This mixed model was analyzed with the MIXED procedure of the SAS System [39]. Variance components of random effects were estimated using the restricted maximum likelihood (REML) method of the MIXED procedure.

\subsection{Genetic parameter estimates}

Individual $\left(h^{2}{ }_{i}\right)$ and family $\left(h^{2}\right)$ heritabilities were estimated as:

$$
\begin{gathered}
h^{2}{ }_{i}=\frac{\sigma_{A}^{2}}{\sigma_{g}^{2}+\sigma_{g f}^{2}+\sigma_{g b}^{2}+\sigma_{e}^{2}} \\
h^{2}=\frac{\sigma_{g}^{2}}{\sigma_{g}^{2}+\sigma_{g f}^{2} / F+\sigma_{g b}^{2} / B+\sigma_{e}^{2} / F B}
\end{gathered}
$$

where $\sigma_{A}^{2}$ is the additive variance which was assumed to be $\sigma_{A}^{2}=$ $4 \cdot \sigma_{g}^{2}, \sigma_{g}^{2}$ is the family variance, $\sigma_{g f}^{2}$ and $\sigma_{g b}^{2}$ are the variance of the family $\times$ fertilization and family $\times$ block interactions, respectively, $F$ and $B$ are the number of fertilization treatments and blocks, respectively, and $\sigma_{e}^{2}$ is the residual variance. Approximate standard errors of individual and family heritabilities were estimated according to Wright [46].

Genetic correlation between traits $x$ and $y$ was estimated as:

$$
r_{G}=\frac{\operatorname{Cov}_{g}(x y)}{\sqrt{\sigma_{f x}^{2} \cdot \sigma_{f y}^{2}}}
$$

where $\operatorname{COV}_{g}(x y)$ is the genetic covariance between the two traits, and $\sigma_{f x}{ }^{2}$ and $\sigma_{f y}{ }^{2}$ are the family variance of traits $\mathrm{x}$ and $\mathrm{y}$, respectively. The covariance between the two traits was calculated as: $\operatorname{COV}_{g}(x y)=$ $1 / 2\left(\sigma_{f(x+y)}^{2}-\sigma_{f x}^{2}-\sigma_{f y}^{2}\right)$ where $\sigma_{f(x+y)}^{2}$ is the family variance of the sum trait $x+y$. Data were standardized (mean $=0$, standard deviation $=1$ ) for each trait to remove scale effects prior to calculating genetic correlations. Standard errors of genetic correlations were estimated as in Falconer [9].
Table II. Results of the mixed model for the fixed effects and variance components $(\%)$ of the random effects. $\sigma_{g}^{2}, \sigma_{g f}{ }^{2}, \sigma_{g b}{ }^{2}$ and

\begin{tabular}{|c|c|c|c|c|c|c|}
\hline & \multicolumn{2}{|c|}{ Fixed effects } & \multicolumn{4}{|c|}{ Variance components (\%) } \\
\hline & Fert. & Block & $\sigma_{g}^{2}$ & $\sigma_{g f}^{2}$ & $\sigma_{g b}^{2}$ & $\sigma_{e}^{2}$ \\
\hline \multicolumn{7}{|l|}{ Growth } \\
\hline Diameter (D) & $* * *$ & $* * *$ & $3.3 * *$ & $2.1 *$ & 0.0 & 86.9 \\
\hline Height $(\mathrm{H})$ & $* * *$ & $* * *$ & $7.9 * *$ & 0.5 & 0.0 & 84.6 \\
\hline \multicolumn{7}{|l|}{ Damage } \\
\hline Wounds (WND) & $* * *$ & $* * *$ & $5.2 * *$ & $2.9 * *$ & 0.9 & 84.1 \\
\hline Leader loss (LL) & $* * *$ & $* * *$ & $2.6^{*}$ & $2.7 *$ & 1.4 & 90.1 \\
\hline \multicolumn{7}{|l|}{ Symptoms } \\
\hline Colour (COL) & $* * *$ & $* * *$ & $4.5 * *$ & 0.0 & 0.8 & 86.5 \\
\hline Defoliation (DEF) & $* * *$ & $* * *$ & $1.8 *$ & 0.5 & 0.8 & 91.6 \\
\hline Resination (RES) & $* * *$ & $* *$ & $4.9 * *$ & 0.0 & 0.0 & 85.8 \\
\hline \multicolumn{7}{|l|}{ Survival } \\
\hline Survival (SUR) & $* *$ & & 0.1 & 1.7 & 1.1 & 95.9 \\
\hline
\end{tabular}
$\sigma_{e}^{2}$ are the variance components for family, family by fertilization interaction, family by block interaction and error, respectively. Significance levels: $* * *=P<0.001$, $* *=P<0.01, *=P<0.05$.

\section{RESULTS}

One year after plantation, almost all seedlings (94\%) showed some pine weevil damage. Severe attacks led to stem girdling (42\% of seedlings) and consequently leader loss, causing important growth losses and stem deformities, and in some cases seedlings death (10\%).

The fertilization effect was highly significant for all the studied traits (Tab. II). All the eight fertilization treatments significantly increased growth and damage and decreased symptoms traits (Fig. 1). In summary, those treatments that did not include $P$ gave intermediate results for all traits. The effect of fertilization has been extensively treated in a companion paper [51] and will be not further considered here.

Differences among families were highly significant for all traits except for Survival (Tab. II). Wounds in the stem of the most attacked family were over the double than those of the less attacked one, whereas leader losses were 4-fold greater in the susceptible family. Unimproved control material (TC and TI) showed significantly lower diameter and height growth than almost all families (Fig. 3). The coastal control (TC) was one of the least attacked, whereas the control seed lot from the interior area of Galicia (TI) was intermediately damaged (Fig. 3).

The estimated heritability on a family mean basis was high (0.6-0.8) for damage and symptoms traits (Tab. III), suggesting an important genetic gain in pine weevil resistance through family selection. Individual heritability was only moderate $(0.1-0.2)$ for both damage and symptoms traits. Additive coefficient of variation was high for damage traits but lower for symptoms traits (Tab. III).

Family $\times$ fertilization $($ Fam $\times$ Fer $)$ interaction was significant for the damage traits and for diameter (Tab. II). The Fam $\times$ Fer interaction was approximately one half of the family variance 


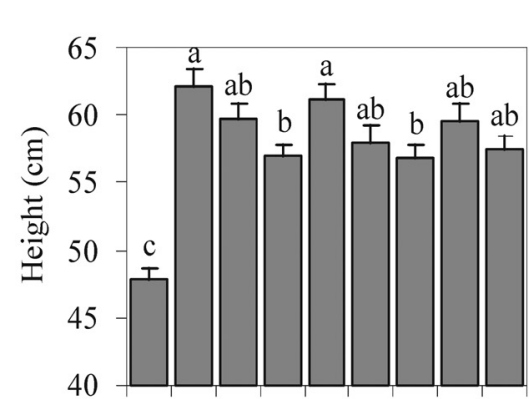

a)

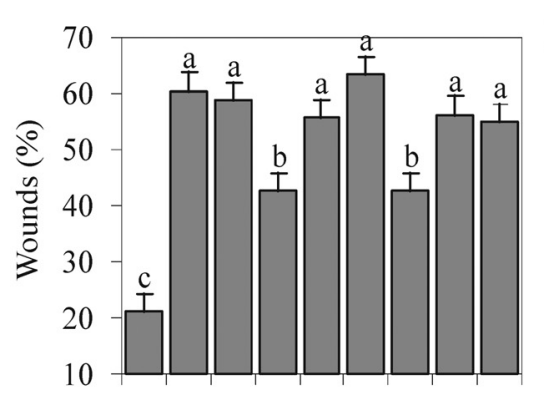

b)

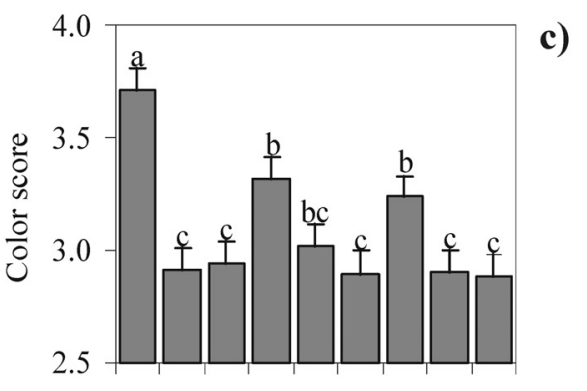

F0 F1 F2 F3 F4 F5 F6 F7 F8

Fertilization treatments

Figure 1. Height growth (a), wounds due to Hylobius abietis damage (b) and color of Pinus pinaster seedlings (c) under different fertilization treatments. Least square means \pm standard errors are presented. Different letters indicate significant $(P<0.05)$ differences between fertilization treatments.

for WND and D, and similar to the family variance in the case of LL. Family $\times$ block interaction was not significant in any case.

Phenotypic and genetic correlations between different traits are presented in Table IV. All damage and symptoms traits were significantly correlated among each other, with genetic correlation close to unity. Survival family mean was also significantly correlated with damage and symptoms traits (Fig. 2b) suggesting pine weevil to be the main cause of mortality. Genetic correlations for those trait pairs including survival should be use with care due to nonsignificant family effects for this trait. In fact, standard errors of these genetic correlations were always very high (Tab. IV). The strong relation between wound and color family means (Fig. 2a) suggest that screening for pine weevil resistance can be carried out by just subjectively assessing the average color of the seedlings.

Damage and symptoms traits were significantly correlated with diameter but not with height (Tab. IV and Fig. 3). Families with greater diameter were more attacked by the pine weevil and showed more symptoms of this attack.
Table III. Genetic parameter estimates. Range of family means, individual heritability $\left(h_{i}{ }^{2}\right) \pm$ standard error (s.e.), family heritability $\left(h_{f}^{2}\right) \pm$ s.e. and additive genetic coefficient of variation $\left(\mathrm{CV}_{\mathrm{A}}\right)$.

\begin{tabular}{lcccc}
\hline & $\begin{array}{c}\text { Range of family } \\
\text { means }\end{array}$ & $h_{i}{ }^{2}$ & $h_{f}{ }^{2}$ & $\mathrm{CV}_{\mathrm{A}}(\%)$ \\
& & & & \\
\hline Growth & $8.3-10.4$ & $0.14 \pm 0.05$ & $0.74 \pm 0.12$ & 15.8 \\
Diameter (mm) & $35.9-56.5$ & $0.34 \pm 0.10$ & $0.89 \pm 0.23$ & 24.9 \\
Height (cm) & & & & \\
Damage & $29.9-66.6$ & $0.23 \pm 0.07$ & $0.80 \pm 0.16$ & 56.8 \\
Wounds (\%) & $10.0-43.2$ & $0.11 \pm 0.04$ & $0.64 \pm 0.09$ & 87.7 \\
Leader loss (\%) & & & & \\
Symptoms & $2.8-3.7$ & $0.20 \pm 0.06$ & $0.81 \pm 0.15$ & 23.7 \\
Colour (0-4) & $3.1-3.7$ & $0.08 \pm 0.03$ & $0.61 \pm 0.08$ & 13.0 \\
Defoliation (0-4) & $2.5-3.3$ & $0.22 \pm 0.07$ & $0.84 \pm 0.16$ & 26.4 \\
Resination (0-4) & $0.8-1.0$ & $0.01 \pm 0.01$ & $0.09 \pm 0.03$ & 5.1 \\
Survival & & & &
\end{tabular}

\section{DISCUSSION}

\subsection{Genetic variation}

This study showed an important genetic variation among $P$. pinaster families in the degree of pine weevil damage. The pine weevil showed markedly preferences to some open-pollinated $P$. pinaster families. Although individual heritability was moderate $(\sim 0.2)$, family heritability was high $(\sim 0.8)$ suggesting that important gains can be expected through family selection. Rouging the seed orchards should consider pine weevil resistance in order to exploit this potential. Judging from the individual heritability estimates, selections within the progeny tests can also be carried out to develop resistant genotypes. The relatively large genetic coefficients of variation (Tab. III) also indicated high expected genetic gains. Irrespective of including pine weevil resistance as an operational trait in the maritime pine breeding program in Galicia, the results presented here indicated that, at least, some susceptible families should be discarded for planting on high weevil risky sites such as second rotation sites, or, alternatively, some resistant families should be preferred. It should be noted that the unimproved commercial seed TC was much less susceptible than most of the tested families (Fig. 2) and thus, the use of genetically improved material appeared to increase the weevil damage risk.

Heritability estimates of tree resistance to insects are usually low or moderate. For example, individual-tree heritability for $P$. pinaster resistance to the moth Dyorictria sylvestrella Ratz. was found about 0.1 [19], whereas heritability for resistance of interior spruce (Picea glauca (Moench) Voss, Picea engelmannii Parry, and their hybrids) to another pine weevil (Pissodes strobi (Peck)) was 0.2-0.4 [15, 16, 18]. These last studies were conducted under low to moderate levels of attack and were based on frequency traits (percentage of plants attacked). The study presented here was conducted under a higher attack level ( $94 \%$ of the seedlings presented some weevil damage) and considered not only the frequency but also the severity of the attack in each seedling (see Materials and methods). It can be expected 

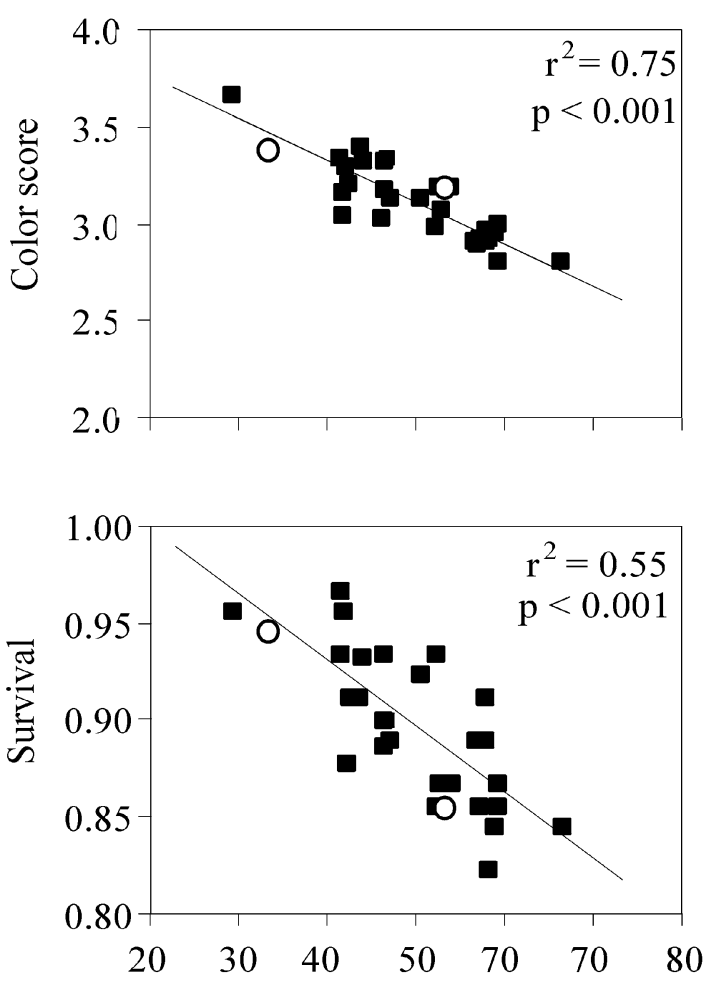

Wounds (\%)

a)

b)

Figure 2. Relationship between wounds in the stem due to Hylobius abietis and color (a) and survival (b) of Pinus pinaster families. Black squares are family means whereas white circles are the two unimproved control seed sources. that higher genetic variation should be found under lower attack levels and using similar frequency traits as in the cited reports. Alfaro et al. [1] confirmed the genetic variation in resistance of interior spruce to $P$. strobi using several traits that measured intensity, severity and tolerance to the insect attack, but heritability of these traits was not reported.

Fertilization had an important effect on pine weevil damage (Fig. 1) and also affected the $P$. pinaster genetic susceptibility to this insect, resulting in significant family $\times$ fertilization $($ Fam $\times$ Fer) interaction (Tab. II). However, judging from the interaction to family variances ratio (Tab. II), the Fam $\times$ Fer interaction was not quantitatively relevant. Given the importance of fertilization on weevil damage and the significant Fam $\times$ Fer interaction for diameter growth (Tab. II), the Fam $\times$ Fer interaction for the damage traits could be a consequence of a genetic variation in the use efficiency of the extra nutrient supplied. Different families responded differently to fertilization (significant Fam $\times$ Fer for diameter growth), and thus fertilization altered their genetic resistance in different ways, resulting in significant Fam $\times$ Fer interaction.

The determination of the resistance mechanisms would be helpful before starting a breeding program for pine weevil resistance. Resistance is though that is likely the combination of several mechanisms such as bark resin canals, traumatic induced resin canals, bark thickness, the presence of needles on stem bases, and other characters such as the presence of feeding repellents, deterrents or toxic compounds [1-3, 11, 17, 23, 27, 43], although the relative importance of each trait probably changes even from genotype to genotype [2]. Particularly, the resin canals appearing in the bark of conifers constitute a physical and chemical barrier to the insect, and the characteristics of those resin canals of Picea spp. have been proved to be strongly related to genetic resistance against other species of

Table IV. Phenotypic correlation of family means $(n=28$, below diagonal) and genetic correlation (above diagonal, standard errors in parenthesis) between different traits. Significant phenotypic Pearson correlations coefficients $(P<0.05)$ are typed in bold.

\begin{tabular}{|c|c|c|c|c|c|c|c|c|}
\hline \multirow[b]{2}{*}{ Trait } & \multicolumn{2}{|c|}{ Damage } & \multicolumn{2}{|c|}{ Growth } & \multirow{2}{*}{$\begin{array}{c}\text { Survival } \\
\text { SUR }\end{array}$} & \multicolumn{3}{|c|}{ Symptoms } \\
\hline & WND & LL & $\mathrm{D}$ & $\mathrm{H}$ & & $\mathrm{COL}$ & DEF & RES \\
\hline \multicolumn{9}{|l|}{ Damage } \\
\hline Wounds (WND) & & $\begin{array}{c}1.02 \\
(0.01)\end{array}$ & $\begin{array}{c}0.55 \\
(0.16)\end{array}$ & $\begin{array}{l}-0.13 \\
(0.20)\end{array}$ & $\begin{array}{l}-1.87 \\
(1.53)\end{array}$ & $\begin{array}{l}-0.94 \\
(0.03)\end{array}$ & $\begin{array}{l}-1.05 \\
(0.02)\end{array}$ & $\begin{array}{l}-1.00 \\
(0.00)\end{array}$ \\
\hline Leader loss (LL) & 0.96 & & $\begin{array}{c}0.32 \\
(0.23)\end{array}$ & $\begin{array}{l}-0.29 \\
(0.21)\end{array}$ & $\begin{array}{l}-1.44 \\
(0.71)\end{array}$ & $\begin{array}{l}-0.89 \\
(0.05)\end{array}$ & $\begin{array}{l}-1.01 \\
(0.01)\end{array}$ & $\begin{array}{l}-0.93 \\
(0.03)\end{array}$ \\
\hline \multicolumn{9}{|l|}{ Growth } \\
\hline Diameter (D) & 0.54 & 0.41 & & $\begin{array}{c}0.74 \\
(0.10)\end{array}$ & $\begin{array}{l}-0.11 \\
(0.64)\end{array}$ & $\begin{array}{l}-0.61 \\
(0.15)\end{array}$ & $\begin{array}{l}-0.66 \\
(0.16)\end{array}$ & $\begin{array}{l}-0.56 \\
(0.64)\end{array}$ \\
\hline Height $(\mathrm{H})$ & 0.14 & 0.09 & 0.57 & & $\begin{array}{l}-0.07 \\
(0.58)\end{array}$ & $\begin{array}{l}-0.18 \\
(0.20)\end{array}$ & $\begin{array}{l}-0.21 \\
(0.23)\end{array}$ & $\begin{array}{l}-0.21 \\
(0.20)\end{array}$ \\
\hline \multicolumn{9}{|l|}{ Survival } \\
\hline Survival (SUR) & -0.74 & -0.76 & -0.34 & -0.06 & & $\begin{array}{l}-0.06 \\
(0.61)\end{array}$ & $\begin{array}{l}-0.06 \\
(0.71)\end{array}$ & $\begin{array}{l}-0.06 \\
(0.61)\end{array}$ \\
\hline \multicolumn{9}{|l|}{ Symptoms } \\
\hline Color (COL) & -0.87 & -0.83 & -0.46 & -0.02 & 0.52 & & $\begin{array}{c}1.01 \\
(0.01)\end{array}$ & $\begin{array}{c}0.90 \\
(0.71)\end{array}$ \\
\hline Defoliation (DEF) & -0.85 & -0.85 & -0.38 & -0.11 & 0.49 & 0.88 & & $\begin{array}{c}1.03 \\
(0.61)\end{array}$ \\
\hline Resination (RES) & -0.95 & -0.88 & -0.46 & -0.03 & 0.58 & 0.83 & 0.80 & \\
\hline
\end{tabular}




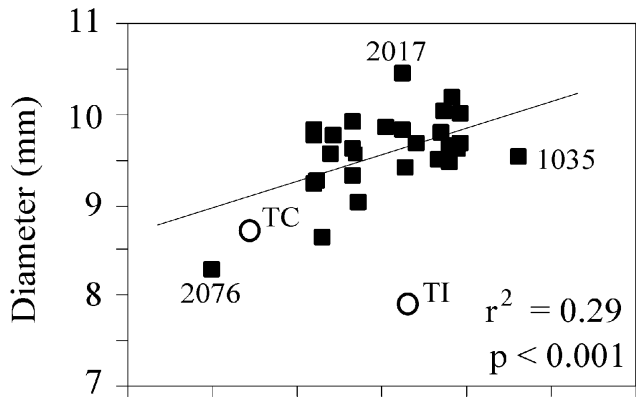

a)

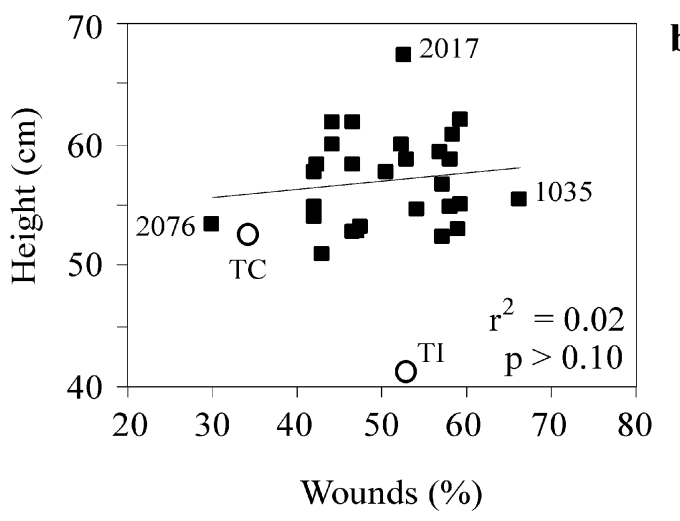

Figure 3. Relationship between damage by Hylobius abietis and diameter (a) and height (b) growth in Pinus pinaster families. Black squares are family means and white circles are the two unimproved control seed sources. Numbers in the figure are the codes of the families and the control seed sources.

pine weevils $[3,16,37,43]$. Besides, several terpenes of the oleoresin of $P$. pinaster have been shown to be related to the susceptibility to Dioryctria sylvestrella $[13,20]$ whereas the resin production of $P$. pinaster after tapping has been shown to be under high genetic control [41]. On the other hand, several plant-derived antifeedants against $H$. abietis have been identified $[6,21,31]$. Other factors such as the genetic variation in the nutrient use efficiency, which probably exist among these maritime pine families [50], may be also interacting by changing the nutrient concentration in the plant tissues and consequently, the pine weevil preferences.

Another important question is that established by Kiss and Yanchuk [18] about what may occur if a plantation is established with just genetically improved resistant material, because the pest response to increased resistance is not expected to be static [30]. Is the genetic variation in susceptibility a real genetic variation in resistance mechanisms or at what extent susceptibility is driven by pine weevil preferences? If pine weevil preferences play a major role, apparent resistant genotypes may be attacked when planted alone without more susceptible neighboring trees. Further research including nonchoice assays and cooperative studies with insect biochemists are needed to answer these questions.

\subsection{Evaluation traits}

The WND trait, measured as the sum of the wound evaluations in each stem tenth, was a reliable damage trait that objec- tively measured the debarked area in the stem caused by pine weevil feeding. However, for operational breeding, this trait was too much hardy to assess. Alternatively, symptoms traits, such as the average seedling color (COL), were easier to assess and were strongly genetically correlated with WND (Tab. IV and Fig. 2), suggesting high correlated responses by selecting through these traits. A complete evaluation of the actual maritime pine breeding population could thus be done by just evaluating the global seedlings appearance.

\subsection{Growth-damage relation}

Diameter growth and weevil damage were both phenotypically and genetically positive correlated (Tab. IV), indicating that faster growing families were much more attacked than slower growing ones. The lack of a similar relation with height growth can be explained because the most attacked plants frequently loss their leaders and, consequently, total height was not possible measured. The relation damage-height was then analyzed on a biased sample, dropping from the analyses those plants with higher damage. It should be noted that diameter was measured after pine weevil attack and thus, it could be also affected by the pest damage, without reflecting the real family potential growth. However, the weevil effect on pine growth is supposed to be negative, and thus, the positive relation between diameter and weevil damage is effectively indicating that inherently fast growing families were more damaged by the insect. In unselected populations, genetic correlations may be due to either pleiotropic effects (multiple effects of individual genes) or to linkage disequilibrium (non-random association between alleles at different loci) [26]. In selected populations, random association between genes controlling different traits could also be the cause. However, this is not likely to be occurring in our study population because all families originated from unrelated plus trees selected for growth and form, restricting selections to healthy trees. So, a random association between low resistance and high growth in the selected population was not favored. Whether pleitropy or linkage is the main cause, the positive relation between pine growth and weevil damage appeared as an important handicap for including the pine weevil resistance as a selection criteria in the breeding program. Selections for growth would result in increased susceptibility, whereas including the resistance as a selection trait would compromise the expected gain in growth. Nevertheless, some fast growing families, such as 2017 (Fig. 3), showed only intermediate levels of weevil attack. Increased susceptibility with tree vigor has been previously found in $P$. pinaster in relation to $D$. sylvestrella attack $[14,19]$ and to the infection by the fungus Melampsora pinitorqua [7, 8]. Kleinhentz et al. [19] also explain this unfavourable correlations in terms of pleiotropy or/and linkage.

Fertilization caused also an important effect on plant growth and weevil damage, the fertilized plants being the thickest and the most attacked (Fig. 1). Whether the effect of both fertilization and genotype in the weevil attack level is a direct effect or is an indirect consequence of the effect on growth is an important question. For example, fertilization can alter the tissue quality by changing nutrient concentrations. Genetic differences in nutrient use efficiency can have a similar effect. Fertilization and genotype could be thus directly affecting attack 
by changing the tissue attractiveness to the weevil. In this case, improving the nutrient utilization, i.e. growth per unit of nutrient in the plant tissues [28], would increase both growth and resistance to the pine weevil because growth is improved without increasing attractiveness to the insect. In relation to this idea, the susceptibility of $P$. pinaster to the fungus $M$. pinitorqua, which was positively correlated with growth, was associated with increased levels of nutrients (phosphorus and potassium) to a greater extent than that expected from only a growth effect [7]. On the other hand, if growth and susceptibility are really genetically linked, breeding for both will become complicated.

\section{CONCLUSIONS}

There was considerable genetic variation in pine weevil damage among the studied $P$. pinaster open-pollinated families. Moderate individual $(\sim 0.2)$ and high family $(\sim 0.8)$ heritability estimates suggested that it is possible to include the resistance to the insect as a selection trait in the Galician maritime pine breeding program.

Screening of pine susceptibility to pine weevil damage can be successfully done by simply evaluating symptoms traits such as the average color of the seedlings.

Pine growth and damage by the pine weevil were phenotypically and genetically positive correlated, fast growing families being more attacked than slower ones. This unfavorable correlation represents an important obstacle for including resistance to the pine weevil in the pine breeding program.

Acknowledgements: This study was supported by the INIA project RTA2-109. We thank the Comunidad de Montes Vecinales en Mano Común de Asados, owner of the land, for giving us the opportunity to plant the progeny trial. Dr. M.J. Lombardero and one anonymous referee are also acknowledged for their useful suggestions.

\section{REFERENCES}

[1] Alfaro R.I., He F., Kiss G., King J., Yanchuk A., Resistance of white spruce to white pine weevil: development of a resistance index, For. Ecol. Manage. 81 (1996) 51-62.

[2] Alfaro R.I., Borden J.H., King J.N., Tomlin E.S., McIntosh R.L., Bohlmann J., Mechanisms of resistance in conifers against shoot infesting insects, in: M.R. Wagner et al. (Eds.), Mechanisms and deployment of resistance in trees to insects, Kluwer Academic Press, Dordnecht, The Netherlands, 2002, pp. 101-126.

[3] Alfaro R.I., vanAkker L., Jaquish B., King J., Weevil resistance of progeny derived from putatively resistant and susceptible interior spruce parents, For. Ecol. Manage. 202 (2004) 369-377.

[4] Álvarez P., Rosa E., Vega P., Vega G., Rodríguez R., Viveros forestales y uso de planta forestal en repoblación en Galicia, in: Proceedings of III Congreso Forestal Nacional, Granada, 2001, pp. 232-238.

[5] Ayres M.P., Wilkens R.T., Ruel J.J., Lombardero M.J., Vallery E., Nitrogen budgets of phloem-feeding bark beetles with and without symbiotic fungi, Ecology 81 (2000) 2198-2210.
[6] Bratt K., Sunnerheim K., Nordenhem H., Nordlander G., Langstrom B., Pine weevil (Hylobius abietis) antifeedants from lodgepole pine (Pinus contorta), J. Chem. Ecol. 27 (2001) 2253-2262.

[7] Desprez Loustau M.L., Wagner K., Components of maritime pine susceptibility to twisting rust - a path coefficient analysis, Eur. J. Plant Pathol. 103 (1997) 653-665.

[8] Desprez Loustau M.L., Wagner K., Influence of silvicultural practices on twisting rust infection and damage in maritime pine, as related to growth, For. Ecol. Manage. 98 (1997) 135-147.

[9] Falconer D.S., Introduction to quantitative genetics, Longman Scientific \& Technical, 3rd ed., New York, 1989.

[10] Fritz R.S., Resistance of hybrid plants to herbivores: genes, environment, or both? Ecology 80 (1999) 382-391.

[11] Hannerz M., Thorsen A., Mattsson S., Weslien J., Pine weevil (Hylobius abietis) damage to cuttings and seedlings of Norway spruce, For. Ecol. Manage. 160 (2002) 11-17.

[12] Herms D.A., Mattson W.J., The dilemma of plants: to growth or defend, Q. Rev. Biol. 67 (1992) 283-335.

[13] Jactel H., Kleinhentz M., Marpeau-Bezard A., Marion-Poll F., Menassieu P., Burban C., Terpene variation in maritime pine constitutive oleoresin related to host tree selection by Dyorictria sylvestrella Ratz. (Lepidoptera, Pyralidae), J. Chem. Ecol. 22 (1996) 1037-1050.

[14] Jactel H., Kleinhentz M., Intensive sylvicultural practices increase the risk of infestation by Dioryctria sylvestrella Ratz (Lepidoptera: Pyralidae), the Maritime pine stem borer, in: J.C. Grégoire et al. (Eds.), Proceedings of Integrating cultural tactics into the management of bark beetle and reforestation pests, USDA, For. Serv. Gen. Tech. Rep. NE-236, 1997, pp. 177-190.

[15] King J.N., Yanchuk A.D., Kiss G.K., Alfaro R.I., Genetic and phenotypic relationships between weevil (Pissodes strobi) resistance and height growth in spruce populations of British Columbia, Can. J. For. Res. 27 (1997) 732-739.

[16] King J.N., Alfaro R.I., Cartwright C., Genetic resistance of Sitka spruce (Picea sitchensis) populations to the white pine weevil (Pissodes strobi): distribution of resistance, Forestry 77 (2004) 269278.

[17] Kiss G., Yanchuk A., Alfaro R.I., Carlson J.E., Manville J.F., Recent advances in research on white pine weevil attacking spruces in British Columbia, in: W.J. Mattson et al. (Eds.), Dynamics of forest herbivory: quest for pattern and principle, USDA For. Serv. Gen. Tech. Rep. NC-183, 1996, pp. 150-158.

[18] Kiss G.K., Yanchuk A.D., Preliminary evaluation of genetic variation of weevil resistance in interior spruce in British Columbia, Can. J. For. Res. 21 (1991) 230-234.

[19] Kleinhentz M., Raffin A., Jactel H., Genetic parameters and gain expected from direct selection for resistance to Dioryctria sylvestrella Ratz. (Lepidoptera: Pyralidae) in Pinus pinaster Ait., using a full diallel mating design, For. Genet. 5 (1998) 147-154.

[20] Kleinhentz M., Jactel H., Menassieu P., Terpene attractant candidates of Dyorictria sylvestrella in maritime pine (Pinus pinaster) oleoresin, needles, liber and headspace samples, J. Chem. Ecol. 25 (1999) 2741-2757.

[21] Klepzic K.D., Schlyter F., Laboratory evaluation of plant-derived antifeedants against the pine weevil Hylobius abietis (Coleoptera: Curculionidae), J. Econ. Entomol. 92 (1999) 644-650.

[22] Leather S.R., Day K.R., Salisbury A., The biology and ecology of the large pine weevil, Hylobius abietis (Coleoptera: Curculionidae): a problem of dispersal? Bull. Entomol. Res. 89 (1999) 3-16.

[23] Lombardero M.J., Ayres M.P., Lorio P.L., Ruel J., Environmental effects on constitutive and inducible resin defences of Pinus taeda, Ecol. Lett. 3 (2000) 329-339. 
[24] Loomis W.E., Growth-differentiation balance vs. carbohydratenitrogen ratio, Proc. Am. Soc. Hort. Sci. 29 (1932) 240-245.

[25] Lorio P.L., Growth-differentiation balance: a basis for understanding southern pine beetle tree interactions, For. Ecol. Manage. 14 (1986) 259-273.

[26] Lynch M., Walsh B., Genetics and analysis of quantitative traits, Sinauer Associates, Inc., Sunderland, Massachusetts, USA, 1997.

[27] Månsson P.E., Schlyter F., Hylobius pine weevils adult host selection and antifeedants: feeding behaviour on host and non-host woody scandinavian plants, Agr. For. Entomol. 6 (2004) 165-171.

[28] Mari S., Jansson G., Jonsson A., Genetic variation in nutrient utilization and growth traits in Picea abies seedlings, Scan. J. For. Res. 18 (2003) 19-28.

[29] Merino A., Rodríguez-López A., Brañas J., Rodríguez-Soalleiro R., Nutrition and growth in newly established plantations of Eucalyptus globulus in northwestern Spain, Ann. For. Sci. 60 (2003) 509517.

[30] Namkoong G., Maintaining genetic diversity in breeding for resistance in forest trees, Ann. Rev. Phytopathol. 29 (1991) 325-342.

[31] Nordlander G., Host finding in the pine weevil Hylobius abietis: effects of conifer volatiles and added limonene, Entomol. Exp. Appl. 59 (1991) 229-237.

[32] O'Reilly-Wapstra J.M., Potts B.M., McArthur C., Davies N.W., Effect of nutrient variability on the genetic-based resistance of Eucalyptus globulus to a mammalian herbivore and on plant defensive chemistry, Oecologia 142 (2005) 597-605.

[33] Orlander G., Nordlander G., Effects of field vegetation control on pine weevil (Hylobius abietis) damage to newly planted Norway spruce seedlings, Ann. For. Sci. 60 (2003) 667-673.

[34] Panda N., Khush G.S., Host Plant Resistance to Insects, CAB International, UK, 1995.

[35] Petersson M., Orlander G., Effectiveness of combinations of shelterwood, scarification, and feeding barriers to reduce pine weevil damage, Can. J. For. Res. 33 (2003) 64-73.

[36] Quiring D., Turgeon J., Simpson D., Smith A., Genetically based differences in susceptibility of white spruce to the spruce bud moth, Can. J. For. Res. 21 (1991) 42-47.

[37] Rosner S., Hannrup B., Resin canal traits relevant for constitutive resistance of Norway spruce against bark beetles: environmental and genetic variability, For. Ecol. Manage. 200 (2004) 77-87.

[38] Sánchez-Rodríguez F., Rodríguez-Soalleiro R., Español E., López C.A., Merino A., Influence of edaphic factors and tree nutritive sta- tus on the productivity of Pinus radiata D. Don plantations in northwest Spain, For. Ecol. Manage. 171 (2002) 181-189.

[39] SAS-Institute, SAS/STAT User's guide, Version 8, SAS Institute Inc., Cary, NC, 1999.

[40] Sydow F.V., Abundance of pine weevils (Hylobius abietis) and damage to conifer seedlings in relation to silvicultural practices, Scan. J. For. Res. 12 (1997) 157-167.

[41] Tadesse W., Auñón F.J., Pardos J.A., Gil L., Alía R., Evaluación precoz de la producción de miera en Pinus pinaster Ait., Investig. Agrar. Sist. Recur. For. 10 (2001) 141-150.

[42] Tuomi J., Fagerstrom T., Niemela P., Carbon allocation, phenotypic plasticity, and induced defenses, in: D.W. Tallamy, Raupp M.J. (Eds.), Phytochemical induction by herbivores, John Wiley \& Sons Inc., New York, 1991, pp. 85-104.

[43] Van Akker L., Alfaro R., Brockley R., Effects of fertilization on resin canal defences and incidence of Pissodes strobi attack in interior spruce, Can. J. For. Res. 34 (2004) 855-862.

[44] Wainhouse D., Hylobius abietis - host utilisation and resistance, in: F. Lieutier et al. (Eds.), Bark and wood boring insects in living trees in Europe, a synthesis, Kluwer Academic Publishers, The Netherlands, 2004, pp. 365-379.

[45] Waring G.L., Cobb N.S., The impact of plant stress on herbivore population dynamics, in: E.A. Bernays (Ed.), Insect-plant interactions, CRC, Boca Raton Fl, 1992, pp. 167-226.

[46] Wright J.W., Introduction to forest genetics, Academic Press, New York, 1976.

[47] Zas R., Foliar nutrient status and tree growth response of young Pseudotsuga menziesii Mirb. (Franco) to nitrogen, phosphorus and potassium fertilization in Galicia (Northwest Spain), Investig. Agrar. Sist. Recur. For. 12 (2003) 75-85.

[48] Zas R., Serrada R., Foliar nutrient status and nutritional relationships of young Pinus radiata $\mathrm{D}$. Don plantations in north-west Spain, For. Ecol. Manage. 174 (2003) 167-176.

[49] Zas R., Merlo E., Fernández-López J., Genetic parameter estimates for Maritime pine in the Atlantic coast of North-west Spain, For. Genet. 11 (2004) 45-53.

[50] Zas R., Fernández-López J., Juvenile genetic parameters and genotypic stability of Pinus pinaster Ait. open pollinated families under different water and nutrient regimes, For. Sci. 51 (2005) 165-174.

[51] Zas R., Sampedro L., Prada E., Lombardero M.J., Fernández-López J., Fertilization increases Hylobius abietis L. damage in Pinus pinaster Ait. seedlings, For. Ecol. Manage. (in press). 